\title{
Country abbreviations
}

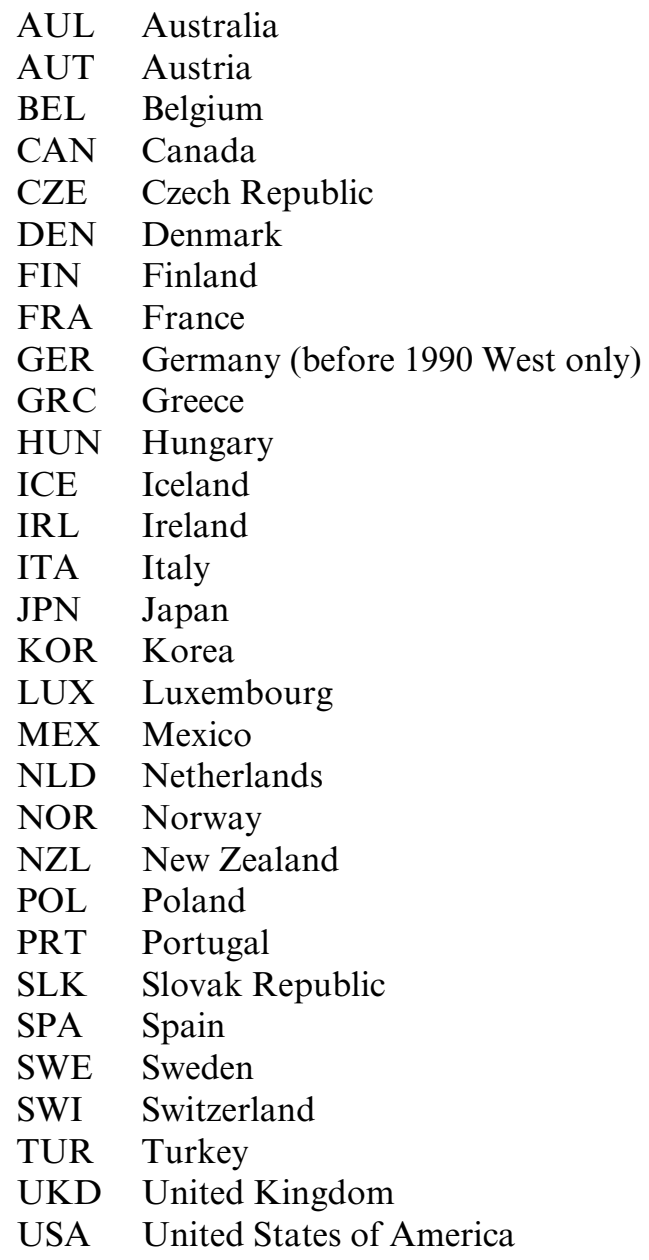


Achim Kemmerling - 9781848447370 Downloaded from PubFactory at 04/26/2023 11:39:39AM via free access 